\title{
Formulasi, Uji kualitas dan Uji Organoleptik Sabun Mandi Padat Menggunakan Bahan Aditif Daun Jambu Biji (Psidium guajava L.)
}

\section{Formulation, quality and Organoleptic Test of Solid Soap with Guava Leaf (Psidium guajava L.) as Additive}

\author{
Sri Handayani dan Aris Tiana Anjali \\ Program Studi Kimia, Fakultas Matematika dan Ilmu Pengetahuan Alam \\ Universitas Negeri Yogyakarta \\ email: handayani@uny.ac.id
}

(tanggal diterima: 13-03-2020 , tanggal disetujui: 01-07-2020)

\section{INTISARI}

Daun jambu biji mengandung senyawa flavonoid, tanin, dan alkaloid yang telah terbukti aktif sebagai antibakteri dan antikanker. Walaupun demikian, daun jambu biji belum pernah digunakan sebagai aditif dalam produk perawatan kulit karena memiliki tekstur yang kasar. Tujuan dari penelitian ini adalah formulasi produksi sabun mandi dengan variasi metode ekstraksi daun jambu biji sebagai aditif, uji kualitas serta uji organoleptiknya.

Formulasi dalam pembuatan sabun dilakukan dengan cara variasi metode ekstraksi daun jambu biji sebagai aditif, yaitu: tanpa aditif sebagai kontrol (A), ekstrak daun jambu dengan pelarut air(B), ekstrak daun jambu biji dengan pelarut minyak nabati (C), dan serbuk kering daun jambu biji sebagai scrub (D). Uji kualitas sabun berdasarkan pada SNI2016 meliputi uji kadar alkali/asam lemak bebas, bahan tak larut dalam etanol dan fraksi lemak tak tersabunkan. Uji organoleptik dilakukan dengan melibatkan 20 orang panelis. Data dianalisis dengan ANOVA-Duncan test.

Uji kualitas sabun menunjukkan semua sampel memenuhi SNI kecuali kadar alkali bebas sabun D. Hasil uji hedonik menunjukkan semua sampel sabun dapat diterima oleh panelis. Berdasarkan uji kualitas dan organoleptic, maka formulasi metode penambahan ekstrak daun jambu biji sebagai aditif yang menghasilkan sabun terbaik adalah ekstraksi menggunakan pelarut air (sabun B). Kajian berikutnya, perlu dilakukan ujiaktivitas biologis terhadap sabun dengan aditif daun jambu karena sangat potensial digunakan sebagai sabun antimikrob

Kata kunci : Sabun padat; daun jambu biji; uji kualitas; uji organoleptik.

\section{ABSTRACT}

Guava leaves have flavonoids, tannins, and alkaloids as main compounds which have been shown to be active as antibacterial and anticarcinogenic agents. However, they have never been used as additives in skin care products because they have a rough texture. The purpose of this research are to formulate the method in the production of bath soap with the leaves as additives, and they were examined in quality and organoleptic tests.

Formulation in production of the soap was carried out by means of variations of the method of extracting guava leaves as additives, namely: without additive as a control (A), with water solvent (B), with vegetable oil solvent (C), and powder dried as a scrub (D). The soap quality tests based on SNI 2016 including tests for alkaline or free fatty acid levels, insoluble ingredients in ethanol and unsaponified fat fractions. Organoleptic test was carried out involving 20 panelists. Data were analyzed by ANOVA-Duncan test.

It was found that soap quality test for all samples meet INS except free alkali levels in D soap. The hedonic test results show that all soap samples can be accepted by panelists. Based on quality and organoleptic tests, the formulation method for adding guava leaf extract as an additive that produces the best soap is extraction using a water solvent (soap B). For the next study, it is necessary to confirm the biological activity of soap with guava leaf additives because it is very potential to be used as an antimicrobial soap.

Keyword: Solid soap; guava leaf; quality test; organoleptic test. 


\section{PENDAHULUAN}

Kulit adalah bagian tubuh manusia yang melindungi tubuh bagian dalam dari gangguan mekanik, fisik, suhu dan radiasi seperti radiasi ultraviolet serta gangguan kuman. Adanya gangguan gangguan tersebut menyebabkan kebutuhan untuk melindungi kulit menggunakan produk perawatan kulit seperti sabun semakin meningkat [1]. Sabun mandi padat ialah sediaan pembersih kulit yang dibuat dari proses saponifikasi atau netralisasi dari lemak, minyak, wax, rosin, atau asam dengan basa organik atau anorganik tanpa menimbulkan iritasi pada kulit [2]. Sabun berkembang bukan hanya digunakan untuk membersihkan kulit, tetapi juga berfungsi untuk melembutkan, memutihkan, maupun menjaga kesehatan kulit. Selain itu sabun juga dapat berfungsi sebagai alat kesehatan yang dapat membersihkan kuman.

Sabun secara kimia adalah hasil reaksi penyabunan antara alkali $\mathrm{NaOH}$ atau $\mathrm{KOH}$ ) dengan trigliserida dari minyak goreng atau minyak nabati [3]. Minyak nabati yang telah dilaporkan untuk pembuatan sabun adalah minyak sawit dan kernel (Liyana \& Rahimi, 2013; Onyegbado, C.O., Iyagba, E.T., Offor, 2002; Awang \& Ahmad, 2001), minyak wijen[7], dan juga minyak jelantah [8].

Untuk dapat berfungsi sesuai dengan kebutuhan, maka perlu bahan tambahan atau aditif dalam pembuatan sabun. Industri sabun yang berkembang saat ini banyak menggunakan bahan kimia untuk menyempurnakan mutu sabun yang dihasilkan sehingga tidak semua sabun aman, khususnya bagi konsumen yang memiliki kulit sensitif [9]. Bahan tambahan dari sumber daya hayati mulai dikembangkan sebagai sabun antibakteri. Salah satu minyak atsiri yang telah dilaporkan aktif sebagai bahan tambahan pada sabun yang berfungsi sebagai antibakteri adalah kemangi [10] dan minyak cengkeh [11]. Oleh karena itu sabun yang dibuat dengan komposisi dari bahan alami menjadi perlu untuk dikembangkan.

Salah satu bahan alam yang dapat digunakan sebagai aditif pada sabun adalah daun jambu biji. Kandungan utama daun jambu biji adalah senyawa fenolik, isoflavonoid, asam galat, catechin, epikatekin, rutin, naringenin, kaempferol. Pulpa kaya akan asam askorbat, karoten (lycopene, $\beta$-karoten dan $\beta$-cryptoxanthin). Biji, kulit dan kulit kayu jambu biji memiliki glikosida, karotenoid dan senyawa fenolik [12]. Ekstrak daun jambu biji putih mengandung senyawa saponin, tanin, steroid, flavanoid, alkaloid, dan triterpen [13]. Penelitian lain menyebutkan bahwa jambu biji diantaranya mengandung tannins, triterpenes dan flavonoid [14].

Metode ekstraksi daun jambu dilaporkan mempengaruhi komponen senyawa hasil dan aktivitas biologisnya [15]. Ekstrak etanol daun jambu biji lokal mampu menghambat pertumbuhan bakteri Staphylococcus aureus dan Bacilus subtilis secara in vitro [16]. Dari beberapa kajian di atas, maka fokus penelitian ini adalah memanfaatkan daun jambu biji sebagai aditif pada sabun mandi padat. Sabun dengan variasi metode penambahan ekstrak daun jambu biji selanjutnya diuji kualitasnya sesuai Standar Nasional Indonesia dan dilanjutkan dengan uji organoleptic. 


\section{METODE PENELITIAN}

\section{1. ALAT DAN BAHAN}

Alat alat yang digunakan dalam penelitian ini adalah kompor, panci, gelas beaker, saringan, neraca analitik, blender, wadah plastik, hand blender/hand mixer, gelas ukur, cetakan silikon/cetakan plastik, erlenmeyer $250 \mathrm{~mL}$, penangas air, hot plate, buret $50 \mathrm{~mL}$, oven, Pompa vakum, Penyaring Buchner, Kertas saring dengan porositas $20 \mu \mathrm{m}$ atau cawan Gooch, Pendingin tegak. Bahan yang digunakan dalam penelitian ini adalah daun jambu biji (Psidium guajava L), akuades, minyak kelapa merk Barco, minyak zaitun yang digunakan adalah minyak zaitun grade B (khusus untuk kosmetik) yang diperoleh dari supplier bahan baku sabun, $\mathrm{NaOH}$ padat, etanol netral (etanol 95\% Merck dipanaskan, dites netral terhadap indicator PP

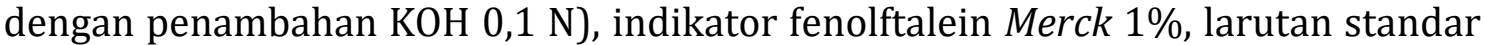
HCl 0,1N (Merck), natrium hidrogen karbonat $10 \mathrm{~g} / \mathrm{l}$ (Merck),, n-heksana (Merck), larutan standar KOH 0,1N (Merck), larutan standar KOH 2N (Merck).

\section{2. CARA KERJA}

\section{Pembuatan sabun}

Secara umum, produksi sabun mandi padat mengikuti metode penelitian sebelumnya dengan sedikit modifikasi formulasi [11]. NaOH Sejumlah 70,7 gram dilarutkan ke dalam akuades sebanyak $190 \mathrm{~mL}$. Campuran diaduk sampai $\mathrm{NaOH}$ terlarut sempurna, kemudian didinginkan sampai mencapai suhu ruang. Sejumlah 360 gram minyak zaitun, 140 gram minyak kelapa, dimasukkan ke dalam wadah plastik. Larutan $\mathrm{NaOH}$ yang sudah dingin dituangkan ke dalam campuran minyak nabati. Campuran kemudian diaduk menggunakan hand blender sampai larutan menjadi trace, kemudian dituang ke dalam cetakan. Setelah 24 jam, sabun yang sudah padat dikeluarkan dan didiamkan dalam udara terbuka selama 4 minggu (curing process). Setelah 4 minggu sabun mandi padat siap diuji kualitas dan organoleptik. Formulasi variasi penggunaan aditif daun jambu biji: tanpa aditif (sabun A sebagai control), ekstrak air daun jambu biji digunakan untuk melarutkan $\mathrm{NaOH}$ (sabun B), ekstrak jambu biji dengan pelarut campuran minyak zaitun dan minyak kelapa (sabun C), serbuk daun jambu biji ditambahkan langsung sebagai scrub (sabun D). Penambahan fragrance vanilla sebanyak 15,5 gram.

\section{Uji kualitas sabun mandi padat.}

Uji kualitas sabun mandi padat dilakukan berdasar Standar Nasional Indonesia 2016 [2] meliputi : Uji kadar alkali bebas atau asam lemak bebas, bahan tak larut dalam etanol dan lemak tak tersabunkan.

\section{Uji bahan tak larut dalam etanol.}

Sejumlah 5 gram sampel sabun mandi padat dilarutkan dengan $200 \mathrm{~mL}$ etanol netral dan dipanaskan dalam rangkaian alat refluks sampai sabun larut seluruhnya. Sampel yang sudah larut disaring menggunakan kertas. Sampel yang 
tersisa dalam labu didih dicuci dengan menggunakan larutan etanol netral. Residu pada kertas saring dicuci dengan menggunakan larutan etanol netral sampai bebas terhadap sabun. Residu pada kertas saring dikeringkan dalam oven pada suhu (100105) ${ }^{\circ} \mathrm{C}$ selama 3 jam kemudian ditimbang. Kemudian Menghitung \% bahan yang tak larut dalam etanol menggunakan persamaan berikut:

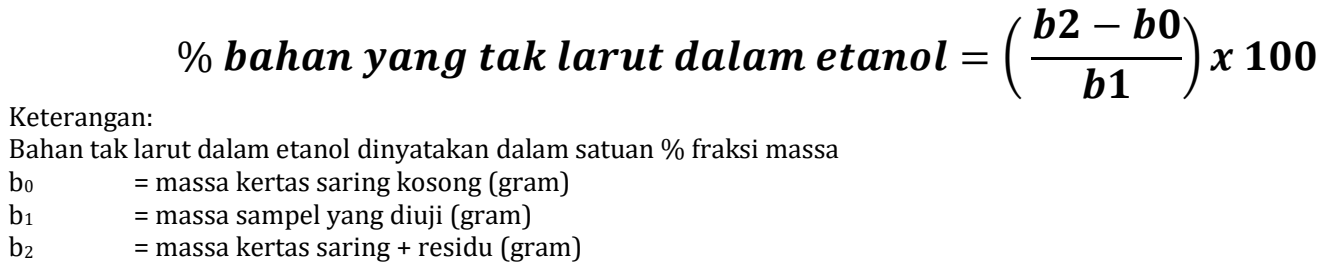

\section{Uji kadar alkali bebas.}

Filtrat dari penentuan bahan tak larut dalam etanol dipanaskan, masukkan indikator fenoftalein. Jika larutan tersebut bersifat asam, titrasi dengan larutan standar $\mathrm{KOH}$ sampai timbul warna merah muda yang stabil. Jika larutan tersebut bersifat alkali, titrasi dengan larutan standar $\mathrm{HCl}$ sampai warna merah tepat hilang. Kemudian menentukan kadar alkali bebas menggunakan persamaan berikut:

Keterangan :

$$
\text { Alkali bebas }=\frac{40 \times v \times N}{b} \times 100
$$

Kadar alkali bebas dinyatakan dalam satuan \% fraksi massa

40 = berat kuivalen $\mathrm{NaOH}$

$\mathrm{b}=$ bobot contoh uji (mg)

$\mathrm{N}=$ normalitas $\mathrm{HCl}$ yang digunakan

$\mathrm{V}=$ Volume $\mathrm{HCl}$ yang digunakan $(\mathrm{mL})$

\section{Uji lemak tak tersabunkan.}

Lima gram sampel sabun ditimbang dan dilarutkan dalam campuran $50 \mathrm{~mL}$ etanol netral dan $50 \mathrm{~mL}$ natrium hidrogen karbonat. Larutan diekstraksi dengan 50 mL larutan n-heksana. Residu yang terbentuk setelah diuapkan lalu dikeringkan dalam oven selama 5 menit. Sampel didinginkan dan ditimbang sampai bobot tetap. Kedalam $10 \mathrm{~mL}$ etanol netral sampel dilarutkan lalu ditambahkan beberapa tetes indikator PP kemudian dititrasi dengan larutan standar KOH 0,1N. Setelah titrasi, tambahkan 10 mL larutan standar KOH 2 N. Kemudian dipanaskan selama 30 menit. Sampel diekstraksi dengan n-heksana. Residu hasil penguapan pelarut dikeringkan lalu ditimbang sampai bobot tetap. Kemudian menghitung \% lemak tak tersabunkan menggunakan persamaan berikut:

Keterangan:

$$
\% \text { Lemak Tak Tersabunkan }=\left(b 1-\frac{V x M}{10000}-b 2\right) x \frac{100}{b 0}
$$

\footnotetext{
Lemak tak tersabunkan dinyatakan dalam satuan \% fraksi massa

b0 = bobot contoh uji (g)

= bobot hasil ekstrak pertama $(\mathrm{g})$

= bobot hasil ekstrak kedua (g)

= rata rata relatif bobot molar dari asam lemak dalam sabun $(\mathrm{g} / \mathrm{mL})$

= volume larutan standar $\mathrm{KOH} \mathrm{0,1} \mathrm{N} \mathrm{yang} \mathrm{digunakan} \mathrm{dalam} \mathrm{penentuan} \mathrm{keasaman} \mathrm{pada} \mathrm{ekstraksi} \mathrm{pertama}(\mathrm{mL})$
} 


\section{Penentuan nilai M total menggunakan GCMS}

Analisis menggunakan GC-MS (Gas Chromatography-Mass Spectroscopy) dilakukan untuk mengidentifikasi rumus molekul serta kemungkinan struktur senyawa yang terdapat dalam minyak nabati yang digunakan dalam pembuatan sabun. Rumus molekul hasil analisis menggunakan instrument GC-MS ini kemudian digunakan untuk menghitung massa molekul relatif dari setiap asam lemak yang terdapat dalam masing masing minyak nabati. Nilai $\mathrm{M}$ dalam perhitungan untuk menentukan fraksi lemak tak tersabunkan dapat diketahui dengan mencari rata rata massa molekul relatif dari kedua minyak nabati yang digunakan.

\section{Pengujian Organoleptik}

Pengujian organoleptik dengan uji hedonik dilakukan dengan melibatkan 20 orang panelis. Terdapat 8 kriteria yang diujikan yaitu aroma, warna, tekstur, tingkat kekerasan, kelembaban, kekesatan, kehalusan dan banyaknya busa. Data dianalisis dengan ANOVA tunggal dan apabila terdapat pengaruh nyata maka dilanjutkan uji Duncan menggunakan program Ms Excel XLSTAT 2014.

\section{HASIL DAN PEMBAHASAN Karakteristik fisik sabun mandi}

Sabun mandi padat dibuat dengan mereaksikan trigliserida dari campuran minyak zaitun [17] dan minyak kelapa dengan natrium hidroksida. Reaksi yang terjadi disebut reaksi saponifikasi. Sabun yang dihasilkan dari penelitian ini memiliki tekstur yang tidak terlalu keras. Selain itu, sabun yang dihasilkan juga memiliki daya pembusaan yang baik yang terlihat dari banyaknya busa yang dihasilkan. Hal tersebut menunjukkan bahwa pemilihan bahan baku pembuatan sabun sudah tepat. Kenampakan sabun hasil penelitian disajikan pada Gambar 1.

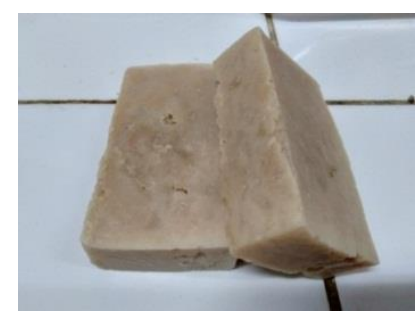

(a). Sabun A

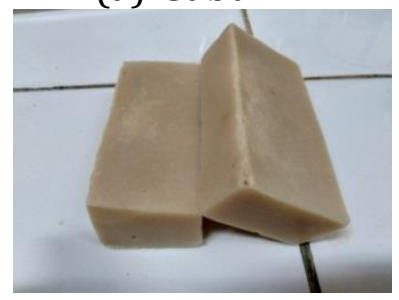

(c). SAbun $\mathbf{C}$

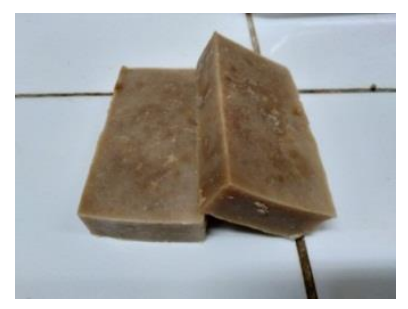

(b). Sabun B

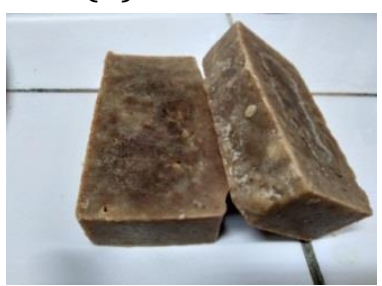

(d). Sabun D

Gambar 1. Sabun mandi padat dengan aditif daun jambu biji 
Sifat fisik sabun mandi padat yang dihasilkan disajikan dalam Tabel 1. Walaupun daun jambu biji memiliki tekstur kasar, namun sabun mandi padat dengan menggunakan ekstrak daun jambu biji baik dengan pelarut air (B) maupun minyak (C) menunjukkan tekstur yang halus. Sabun dengan dan tanpa ekstrak daun jambu biji tidak menunjukkan tekstur yang berbeda. Dengan demikian, tekstur kasar daun jambu biji tidak menghalangi pemanfaatannya sebagai aditif pada sabun menggunakan metode ekstraksi. Di sisi lain, sabun D yang menggunakan serbuk daun jambu memiliki tekstur yang kasar. Tekstur kasar pada sabun D ini memiliki kelebihan khusus yaitu dapat digunakan menjadi sabun scrub dengan serbuk kasar daun jambu sebagai eksfoliat alami. Scrub dari bahan alam sudah sangat berkembang untuk menggantikan scrub dari silika [18]

Tabel 1. Sifat Fisik Sabun Mandi Padat

\begin{tabular}{|c|c|c|c|c|}
\hline Parameter & Sabun A & Sabun B & Sabun C & Sabun D \\
\hline Warna & $\begin{array}{l}\text { Putih } \\
\text { Kecoklatan }\end{array}$ & Coklat & Kekuningan & $\begin{array}{l}\text { Coklat kehijauan } \\
\text { pekat }\end{array}$ \\
\hline Aroma & $\begin{array}{l}\text { Fragrance } \\
\text { vanilla }\end{array}$ & $\begin{array}{l}\text { Fragrance } \\
\text { Vanilla dan } \\
\text { masih tercium } \\
\text { aroma khas } \\
\text { daun jambu } \\
\text { biji }\end{array}$ & $\begin{array}{l}\text { Fragrance } \\
\text { vanilla }\end{array}$ & $\begin{array}{l}\text { Aroma khas daun } \\
\text { jambu biji, tidak } \\
\text { tercium aroma } \\
\text { fragrance vanilla }\end{array}$ \\
\hline $\begin{array}{l}\text { Tekstur } \\
\text { Permukaan }\end{array}$ & Halus & Halus & Halus & Kasar \\
\hline
\end{tabular}

\section{Uji Kualitas Sabun}

Data hasil uji kualitas sabun dengan penambahan daun jambu biji ditampilkan pada Tabel 2 .

Tabel 2. Hasil Uji Kualitas Sabun Mandi Padat

\begin{tabular}{|c|c|c|c|c|c|}
\hline Parameter & $\begin{array}{l}\text { Sabun A } \\
(\%)\end{array}$ & $\begin{array}{l}\text { Sabun B } \\
(\%)\end{array}$ & $\begin{array}{l}\text { Sabun C } \\
(\%)\end{array}$ & $\begin{array}{l}\text { Sabun D } \\
(\%)\end{array}$ & $\begin{array}{l}\text { SNI2016 } \\
(\%)\end{array}$ \\
\hline Alkali Bebas & - & - & - & 0,1704 & $<0,1$ \\
\hline Asam Lemak Bebas & 1,9909 & 1,1280 & 1,4664 & - & $<2,5$ \\
\hline $\begin{array}{l}\text { Fraksi Lemak Tak } \\
\text { Tersabunkan }\end{array}$ & 0,0293 & 0,0568 & 0,0528 & 0,0941 & $<0.5$ \\
\hline $\begin{array}{l}\text { Bahan Tak Larut } \\
\text { dalam Etanol }\end{array}$ & 1 & 1 & 1,67 & 2,33 & 5 \\
\hline
\end{tabular}

Alkali/Asam Lemak Bebas. Pengujian alkali bebas sabun dengan penambahan daun jambu biji dilakukan pada minggu keempat waktu penyimpanan. Berdasarkan hasil pengujian sampel A, B dan $\mathbf{C}$ mengandung asam lemak bebas, sedangkan sampel D mengandung alkali bebas. Syarat mutu alkali bebas menurut SNI adalah $<0,1 \%$ sedangkan syarat mutu asam lemak bebas menurut SNI adalah $<2,5 \%$. 
Asam lemak bebas adalah asam lemak yang berada dalam sampel sabun, tetapi tidak terikat persenyawaan dengan natrium ataupun senyawa trigliserida Sampel A, B dan C masing masing memiliki jumlah asam lemak bebas sebesar $1,1280 \%, 1,4664 \%$ dan 1,9909\%. Ketiga sampel tersebut telah memenuhi standar kualitas sabun yang ditetapkan oleh Badan Standarisasi Nasional. Data pada Tabel 2 secara umum menunjukkan bahwa penambahan aditif daun jambu biji tidak menurunkan kualitas sabun berdasar SNI. Hanya sabun D yang nilai alkali bebasnya tidak sesuai standar.

Sampel D tidak mengandung asam lemak bebas karena semua asam lemak habis bereaksi namun memiliki kadar alkali bebas sebesar 0,17\%. Nilai tersebut tidak memenuhi standar yang telah ditetapkan oleh Badan Standar Nasional Indonesia. Kelebihan alkali pada suatu proses pembuatan sabun dapat disebabkan karena adanya jumlah alkali yang melebihi jumlah alkali yang digunakan untuk melakukan proses saponifikasi keseluruhan minyak menjadi sabun. Sabun dihasilkan melalui reaksi saponifikasi antara asam lemak dalam minyak/lemak dengan alkali. Sabun yang baik adalah sabun yang dihasilkan dari reaksi yang sempurna antara asam lemak dan alkali dan diharapkan tidak terdapat residu/sisa setelah reaksi. Namun tidak selamanya reaksi yang diharapkan dapat berlangsung sempurna [19]. Nilai alkali bebas pada sabun D yang melebihi Standar Nasional Indonesia juga kemungkinan dipengaruhi oleh metode ekstraksi. Serbuk kering daun jambu biji yang dimasukkan langsung pada sabun, diduga menyebabkan nilai alkali bebas pada sabun menjadi lebih tinggi. Daun jambu biji mengandung senyawa alkaloid yang bersifat basa [20], sehingga diduga dapat menyebabkan nilai alkali bebas sabun D melebihi standar yang telah ditentukan. Pada uji alkali bebas/asam lemak bebas ini, metode ekstraksi yang terbaik adalah ekstraksi daun jambu biji menggunakan pelarut air (B). Nilai asam lemak bebas sabun dengan penambahan ekstrak air daun jambu biji (Sabun B) menunjukkan nilai yang terkecil karena zat yang terlarut dalam air seperti flavonoid dan tanin bersifat asam sehingga tidak meningkatkan persentase alkali bebas dalam sabun.

\section{Uji Bahan Tak Larut Dalam Etanol.}

Analisis bagian yang tak larut dalam etanol dilakukan untuk mengetahui banyaknya komponen yang tidak larut dalam alkohol yang terdapat pada sabun [9]. Dari hasil pengujian, sabun A dan B memiliki kadar bahan tak larut dalam etanol sebesar 1\%, sabun C sebesar 1,67\% dan sabun D sebesar 2,33\%. Nilai tersebut sudah memenuhi standar Nasional Indonesia yang ditetapkan yaitu $<5 \%$. Nilai bahan tak larut dalam etanol dipengaruhi oleh metode penambahan daun jambu biji. Sabun D memiliki nilai bahan tak larut dalam etanol yang paling tinggi dibandingkan kesemua sampel sabun karena serbuk kering daun jambu biji yang ditambahkan pada sabun mengandung beberapa senyawa non polar. Daun jambu biji mengandung antara lain tanin, minyak atsiri, flavonoid, alkaloid, ursolic, oleanolic, karoten, vitamin B1, B2, B3, B6, dan vitamin $\mathrm{C}$ serta resin, selain avicularin dan guaijaverin [14]. Senyawa-senyawa tersebut beberapa diantaranya bersifat nonpolar seperti minyak atsiri, alkaloid dan karoten. Senyawa-senyawa non polar tidak larut dalam alkohol. Hal tersebut menyebabkan sabun D (penambahan serbuk 
daun jambu biji) memiliki kadar bahan tak larut dalam etanol yang lebih tinggi dibandingkan sabun tanpa penambahan daun jambu biji.

\section{Uji Fraksi Lemak Tak Tersabunkan.}

Fraksi tak tersabunkan merupakan senyawa-senyawa yang tidak dapat bereaksi dengan alkali. Untuk menghitung fraksi lemak tak tersabunkan dalam sabun, perlu diketahui nilai M minyak total kedua minyak nabati. Nilai M adalah massa molekul relative asam lemak yang terdapat dalam sabun. Asam lemak dalam sabun ini berasal dari minyak nabati yang digunakan yaitu kelapa dan minyak zaitun, sehingga digunakan rata-rata massa molekul relatif total masing-masing minyak nabati. Nilai M total dianalisis menggunakan GCMS. Dari hasil analisis, diperoleh nilai M total sebesar 240,62 kg/mol (Tabel 3).

Tabel 3. Massa molekul relative campuran minyak nabati

\begin{tabular}{|l|l|l|}
\hline No. & Minyak Nabati & Massa molekul relatif \\
\hline 1. & Minyak kelapa & 211,31 \\
\hline 2. & Minyak zaitun & 269,93 \\
\hline & M rata-rata & 240,62 \\
\hline
\end{tabular}

Sabun dengan penambahan bahan aditif daun jambu biji ini masing masing memiliki nilai fraksi lemak tak tersabunkan untuk sampel A, B, C, D masing masing sebesar 0,0293\%; 0,0568\%; 0,0528\% dan 0,0941\%. Sedangkan syarat mutu sabun mandi yang ditetapkan oleh SNI sebesar $<0,5 \%$ sehingga semua sampel sabun memenuhi SNI.

Kadar fraksi tak tersabunkan juga dipengaruhi oleh konsentrasi $\mathrm{NaOH}$. Fraksi lemak tak tersabunkan menurun seiring dengan bertambahnya konsentrasi $\mathrm{NaOH}$. Metode penambahan daun jambu biji juga dapat mempengaruhi tinggi rendahnya nilai fraksi lemak tak tersabunkan. Daun jambu biji mengandung sejumlah karoten dan pigmen serta sterol. Senyawa senyawa tersebut merupakan senyawa yang tidak dapat tersabunkan. Adanya senyawa senyawa tersebut menyebabkan nilai fraksi lemak tak tersabunkan sabun dengan penambahan daun jambu biji menjadi lebih tinggi. Nilai fraksi lemak tak tersabunkan yang melebihi standar SNI dan kadar alkali bebas yang tinggi pada sabun D berarti bahwa reaksi tidak berjalan dengan sempurna.

\section{Uji Organoleptik}

Gambar 2, merupakan hasil analisa penilaian tingkat kesukaan panelis terhadap produk sabun. Tingkat kesukaan digambarkan menggunakan skala hedonik 1-5. Semakin tinggi skala hedonik maka sabun semakin disukai oleh panelis.'

Sabun B dan sabun C memiliki nilai hedonik yang lebih tinggi dengan kata lain lebih disukai oleh konsumen/panelis. Penambahan daun jambu biji memberikan nilai lebih bagi sabun, karena sangat mempengaruhi warna dan tekstur sabun. 


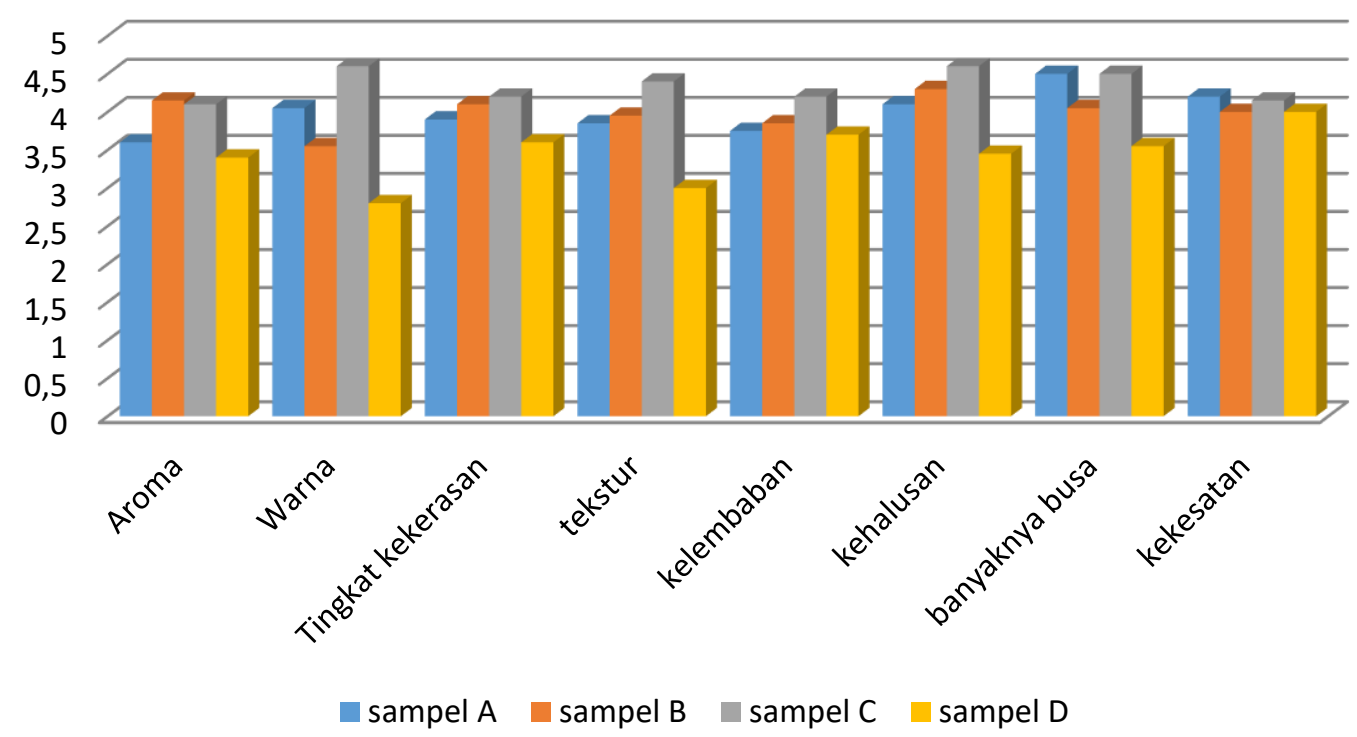

Gambar 2. Histogram Uji Organoleptik

Hasil analisis keragaman (ANOVA) dilanjutkan dengan uji Duncan, diperoleh perbedaan yang signifikan pada hampir semua aspek yang diujikan yaitu aroma, warna, tingkat kekerasan, tekstur, kehalusan dan daya pembusaan. Sedangkan untuk aspek kelembaban dan kekesatan tidak menunjukkan adanya perbedaan yang signifikan. Perbedaan dari aspek aspek tersebut khususnya pada aspek warna, aroma, dan tekstur dapat dipengaruhi oleh penambahan daun jambu biji pada sabun.

Secara keseluruhan, baik sabun A, B, C maupun D dapat diterima oleh konsumen/panelis. Skala hedonik rata rata untuk sabun $\mathbf{A}$ dan $\mathbf{B}$ adalah 4 dan sabun C adalah 4,35 yang berarti sabun tersebut disukai oleh panelis. Sedangkan sabun D memiliki rata rata skala hedonik 3,43 yang menunjukkan sabun D masih cukup disukai panelis (dapat diterima).

\section{Formulasi Terbaik Sabun}

Kualitas sabun dapat dipengaruhi oleh komposisi bahan baku pembuatan sabun, kesempurnaan proses reaksi saponifikasi maupun metode penambahan bahan alam yang digunakan sebagai aditif dalam pembuatan sabun. Variasi metode formulasi penambahan daun jambu biji sebagai aditif mempengaruhi kenampakan fisik, kualitas sabun berdasarkan SNI maupun tingkat kesukaan panelis terhadap sabun yang dihasilkan.

Berdasarkan hasil uji kualitas dan uji organoleptik, diketahui bahwa formulasi sabun terbaik adalah sabun $\mathbf{B}$ atau sabun dengan penambahan daun jambu biji yang diekstrak dengan pelarut air. Sabun B memberikan hasil yang paling baik untuk uji kualitas serta memiliki skala hedonik yang baik (skala 4) yang berarti 
sabun B disukai oleh panelis. Dari hasil uji organoleptic, sabun C juga memiliki skala yang baik, namun dari segi kualitas, sabun $\mathbf{B}$ lebih unggul dibandingkan dengan sabun $\mathbf{C}$.

\section{KESIMPULAN}

Metode formulasi penambahan ekstrak daun jambu biji pada sabun mempengaruhi tekstur fisik, kualitas serta tingkat kesukaan sabun oleh panelis (tingkat hedonik). Walaupun demikian, secara umum semua sampel sabun memenuhi standar SNI kecuali sampel $\mathbf{D}$ yang tidak memenuhi kadar alkali bebas. Berdasarkan uji kualitas dan organoleptic, maka formulasi metode penambahan ekstrak daun jambu biji sebagai aditif yang menghasilkan sabun terbaik adalah ekstraksi menggunakan pelarut air (sabun B).

\section{DAFTAR PUSTAKA}

[1] Y. Sukawaty, H. Warnida, and A. V. Artha, "Formulasi Sediaan Sabun Mandi Padat Ekstrak Etanol Umbi Bawang Tiwai (Eleutherine Bulbosa ( Mill .) Urb .)," Media Farm., vol. 13, no. 1, pp. 14-22, 2016.

[2] BSN, "Sabun mandi padat, SNI 3532:2016." 2016.

[3] Bruice P Y, Organic Chemistry, Fifth edit. USA: Pearson Prentice Hall, 2007.

[4] Rafiqa Liyana Binti Rahimi, "To Study Optimum Parameter In The Soap Production Derived From Palm Kernel Oil and Palm Oil by Saponification," Faculty of Chemical and Natural Resources Engineering, Universiti Malaysia Pahang, 2013.

[5] C. O. Onyegbado, E. T. Iyagba, and O. J. Offor, "Solid Soap Production using Plantain Peel Ash as Source of Alkali," J. Appl. Sci. Environ. Mgt, vol. 6, no. 1, pp. 73-77, 2002.

[6] R. Awang and S. Ahmad, "Properties of Sodium Soap Derived from Palm-Based Dihtdroxystearic Acid," J. Oil Palm Res., vol. 13, no. 2, pp. 33-38, 2001.

[7] V. Semilin, "Production of Soap From Sesamum Indicum (Sesame Seed)," Universiti Malaysia Pahang, 2014.

[8] S. Asmira, "Semi-Automated Machine to make Soap from Used," Universiti Teknikal Malaysia Melaka, 2015.

[9] L. Casalla, "Karakteristik sabun tallow dengan penambahan madu sebagai antioksidan laura casalla," J. Produksi dan Teknol. Peternak., 2014.

[10] R. Muthmainah, D. Rubiyanto, and T. S. Yulianto, "Formulasi Sabun Cair Berbahan Aktif Minyak Kemangi sebagai Antibakteri dan Pengujian terhadap Staphylococcuc Aureus," Indo.J.Chem.Res, vol. 1, no. 1, pp. 44-50, 2014.

[11] S. Handayani, S. Kristianingrum, and A. Rakhmawati, "Standard Quality and Antibacterial Activity Tests of Clove Oil in Solid Soap Production Against Staphylococcus aureus, Staphylococcus epidermidis and Escherichia coli," Orient. J. Chem., vol. 34, no. 5, pp. 2410-2417, 2018.

[12] S. M. Barbalho, "Psidium Guajava (Guava): A Plant of Multipurpose Medicinal Applications," Med. Aromat. Plants, vol. 01, no. 04, 2012, doi: 10.4172/2167- 
0412.1000104.

[13] N. Thakur and V. Arya, "Preliminary phytochemical analysis of the extracts of psidium leaves," Middle - East J. Sci. Res., vol. 19, no. 11, pp. 1421-1424, 2014, doi: 10.5829/idosi.mejsr.2014.19.11.11415.

[14] J. V. Kamath, N. Rahul, C. K. A. Kumar, and S. Mohana Laksmi, "Psidium guajava L A review," Int. J. Green Pharm., vol. 2, no. March 2008, pp. 9-12, 2014.

[15] R. E. Daud Fajar Mohammad, Sadiyah R. Esti, "Pengaruh Perbedaan Metode Ekstraksi terhadap Aktivitas Antioksidan Ekstrak Etanol Daun Jambu Biji ( Psidium Guajava L .) Berdaging Buah Putih," Pros. SNaPP2011 Sains, Teknol. dan Kesehat., vol. 2, no. 2089-3582, pp. 55-62, 2011.

[16] L. Yulisma, "Staphylococcus aureus dan bacilus subtilis secara in vitro 1," Issn 1907 - 3089 E-Issn 2651-5869, vol. 10, no. 2, pp. 1-6, 2018.

[17] A. Widyasanti, A. Y. Rahayu, and S. Zein, "Pembuatan Sabun Cair Berbasis Virgin Coconut Oil (VCO) dengan Penambahan Minyak Melati (Jasminum Sambac) sebagai Essential Oil," J. Teknotan, vol. 11, no. 2, p. 1, 2017, doi: 10.24198/jt.vol11n2.1.

[18] S. W. Trew and Z. B. Gould, Making Natural Soaps. New York: Alpha Books, 2010.

[19] T. K. B. A. S. dan G. A. K. Erliza Hambali, "Aplikasi Dietanolamida Dari Asam Laurat Minyak Inti Sawit Pada Pembuatan Sabun Transparan," J. Agroindustrial Technol., vol. 15, no. 2, pp. 46-53, 2012.

[20] W. C. Lee, R. Mahmud, R. Noordin, S. P. Piaru, S. Perumal, and S. Ismail, "Alkaloids content, cytotoxicity and anti-Toxoplasma gondii activity of Psidium guajava L. and Tinospora crispa," Bangladesh J. Pharmacol., vol. 7, no. 4, 2012, doi: 10.3329/bjp.v7i4.12499. 